\title{
ANALISIS FAKTOR-FAKTOR YANG BERPENGARUH TERHADAP RETURN SAHAM PADA PERUSAHAAN MANUFAKTUR SEKTOR INDUSTRI BARANG KONSUMSI SUB SEKTOR MAKANAN DAN MINUMAN YANG TERCATAT AKTIF DI BURSA EFEK INDONESIA PERIODE 2013-2017
}

\author{
Dionisius Sole \\ Program Studi Magister Manajemen Universitas Tarumanagara \\ dionisiussole857@yahoo.co.id
}

Masuk : 07-12-2019, revisi : 18-12-2019 diterima untuk diterbitkan : 19-12-2019

\begin{abstract}
This research aims to examine and analyze the factors that influence stock returns in manufacturing companies in the consumer goods and food sub-sector listed on the Indonesia Stock Exchange (IDX). The independent variables in this research are Earning Per Share (EPS), Price Earning Ratio (PER), Return On Assets (ROA), and Firm Size. The dependent variable in this research is stock returns. The number of observations in this research were 55 of 11 companies multiplied by 5 years. This research uses purposive sampling method. Empirical results in this research using the SPSS program using multiple linear regression analysis methods. The results of this reserach indicate that return on assets (ROA) has a significant effect on stock returns. While Earnings Per Share (EPS), Price Earning Ratio (PER), and Firm Size have no significant effect on stock returns. These results indicate that investors should pay attention to Return On Assets (ROA) in their investment strategies. As well as looking at the small effect of the independent variables on the dependent variable, it is suggested the need for caution in generalizing the results of this research.
\end{abstract}

Keywords : Stock Return; Earning Per Share (EPS); Price Earning Ratio (PER); Return on Asset (ROA); Firm Size

\begin{abstract}
Abstrak : Penelitian ini bertujuan untuk menguji dan menganalisis faktor-faktor yang mempengaruhi return saham pada perusahaan manufaktur industri barang konsumsi sub sektor makanan dan minuman yang terdaftar di Bursa Efek Indonesia (BEI). Variabel independen dalam penelitian ini adalah Earning Per Share (EPS), Price Earning Ratio (PER), Return On Asset (ROA), dan Firm Size. Variabel dependen dalam penelitian ini adalah Return saham. Jumlah observasi dalam penelitian ini adalah 55 dari 11 perusahaan dikali dengan 5 tahun. Penelitian ini menggunakan metode purposive sampling. Hasil empiris dalam penelitian ini menggunakan program SPSS dengan menggunakan metode analisis regresi linear berganda. Hasil penelitian ini menunjukkan bahwa return on asset (ROA) berpengaruh signifikan terhadap return saham. Sedangkan earning per share (EPS), price earning ratio (PER), dan firm size tidak berpengaruh signifikan terhadap return saham. Hasil tersebut mengindikasikan bahwa investor sebaiknya memperhatikan return on asset (ROA) dalam strategi investasinya. Serta melihat dari kecilnya pengaruh variabel independen terhadap variabel dependen, maka disarankan perlunya kehati-hatian dalam melakukan generalisasi hasil penelitian ini.
\end{abstract}

Kata Kunci : Return Saham; Earning Per Share (EPS); Price Earning Ratio (PER); Return On Asset (ROA); Firm Size

\section{Latar Belakang}

Penelitian lain yang berkaitan dengan faktor-faktor yang mempengaruhi return saham antara lain penelitian Farkhan dan Ika (2012) yang meneliti pengaruh Rasio Keuangan terhadap Return Saham Perusahaan Manufaktur di Bursa Efek Indonesia. Hasilnya menunjukkan bahwa 
Debt to Equity Ratio tidak berpengaruh secara signifikan terhadap Return Saham, sedangkan Price Earning Ratio mempunyai pengaruh yang signifikan terhadap return saham. Selain itu, Arista (2012) yang meneliti faktor-faktor yang mempengaruhi Return Saham. Hasilnya menunjukkan Price to Book Value mempunyai pengaruh signifikan terhadap return saham, sedangkan earnings per share tidak berpengaruh secara signifikan terhadap return saham.

Menurut penelitian Hardiningsih, dkk (2002), return on asset (ROA) terbukti berpengaruh signifikan terhadap return saham. Hasil yang berbeda ditunjukan oleh Rohmah dan Rina (2004) menyatakan bahwa return on asset (ROA) tidak memberikan pengaruh yang signifikan terhadap return pemegang saham Gitman dalam Raida (2010) menyatakan bahwa dari segi kemauan dan prestise investor secara alternatif akan lebih meyakini pada perusahaan yang berukuran lebih besar untuk menanamkan dananya dari pada perusahaan yang berukuran lebih kecil. Soleman (2008:414) menyatakan bahwa semakin besar ukuran perusahaan akan mencerminkan pula kemampuan perusahaan untuk dapat membiayai kebutuhan dananya (kesempatan investasi) pada masa yang akan datang.

Berdasarkan latar belakang diatas, penelitian ini menarik untuk diteliti karena hasil penelitian tentang return saham kebanyakan memberikan hasil yang tidak konsisten. Oleh karena itu, pada penelitian kali ini variable variable yang digunakan lebih kompleks dari penelitian-penelitian sebelumnya.

\section{Tinjauan Pustaka \\ Return Saham}

Pengertian return adalah hasil yang diperoleh dari investasi sedangkan saham merupakan tanda bukti kepemilikan dalam suatu perusahaan yang berbentuk Perseroan Terbatas (PT). Jadi Return Saham merupakan pembayaran yang diterima karena hak kepemilikannya, ditambah dengan harga perubahan pada harga pasar, yang dibagi dengan harga awal (Van Horne, JC dan Walker, JM, 2005).

\section{Earning Per Share (EPS)}

Menurut Sutrisno (2007:223), Earnings Per Share atau laba per lembar saham merupakan ukuran kemampuan perusahaan untuk menghasilkan keuntungan perlembar saham pemilik. Laba yang digunakan sebagai ukuran adalah laba sebagai pemilik atau EAT.

\section{Price Earning Ratio (PER)}

Price Earnings Ratio (PER) mengindikasikan besarnya rupiah yang harus dibayarkan investor untuk memperoleh satu rupiah earnings perusahaan. Dengan kata lain PER menunjukan besarnya harga setiap satu rupiah earnings perusahaan. PER merupakan ukuran harga relatif dari sebuah saham perusahaan (Tandelilin, 2001:243). Rasio Price Earnings Ratio (PER) mencerminkan pertumbuhan laba perusahaan. Semakin tinggi rasio ini, semakin tinggi pertumbuhan laba yang diharapkan oleh pemodal (Husnan dan Pudjiastuti, 2002: 77).

\section{Return On Asset (ROA)}

Menurut Kasmir (2012:202), semakin tinggi nilai ROA maka kinerja perusahaan dianggap semakin baik dan demikian pula sebaliknya. Mendukung pernyataan tersebut, Saqafi (2012) dalam penelitiannya menyatakan bahwa ROA memiliki hubungan dengan tingkat pengembalian (return) dari suatu investasi dimasa yang akan datang. Meningkatnya ROA berarti perusahaan dianggap mampu menghasilkan laba perusahaan yang tinggi dan sebagai dampaknya harga saham perusahaan meningkat. Terjadinya peningkatan harga saham berakibat pula pada peningkatan return saham perusahaan yang diterima pemegang saham. Pernyataan tersebut didukung oleh hasil penelitian yang dilakukan oleh Daljono (2013), Haghiri (2012), Kabajeh et al. (2012) serta Har \& Ghafar (2015) bahwa ROA memiliki hubungan yang positif terhadap return saham. 


\section{Firm Size}

Ukuran perusahaan menunjukan suatu perusahaan apakah tergolong dalam perusahaan kecil, perusahaan menengah, atau perusahaan besar. Kriteria ukuran perusahaan dapat dinilai dari omset penjualan, jumlah produk yang dijual, modal perusahaan dan total aset. Perusahaan yang besar dianggap mempunyai risiko yang lebih kecil dibandingkan dengan perusahaan yang kecil karena perusahaan yang besar dianggap lebih mempunyai akses ke pasar modal (Elton dan Gruber, 1994 dalam Jogiyanto, 2007).

\section{Metodologi Penelitian}

Rancangan penelitian yang digunakan dalam penelitian ini adalah pengujian hipotesis kerena penelitian ini dilakukan untuk menganalisis faktor-faktor yang berpengaruh terhadap Return Saham. Jenis data yang digunakan berupa data panel yaitu gabungan dari data cross sectional dan time series pada perusahaan manufaktur industri barang konsumsi sub sektor makanan dan minuman yang tercatat aktif di Bursa Efek Indonesia selama periode 2013-2017. Alat analisis yang digunakan dalam penelitian ini adalah regresi linear berganda, dengan menggunkan software SPSS 22.

\section{Variabel dan Pengukuran}

Variabel Dependen return saham:

$$
\text { Rit }=\frac{\text { Pit }- \text { Pit }-1}{\text { Pit }-1} X 100 \%
$$

Sumber: (Jogiyanto, 2003: 110)

Variabel Independen :

1. Earning Per Share (EPS)

$$
\text { Earnings Per Share }=\frac{\text { laba bersih setelah bunga dan pajak }}{\text { iumlah saham yana beredar }}
$$

Sumber: (Eduardus Tandelilin, 2001: 241-242)

2. Price Earning Ratio (PER)

$$
\text { Price Earning Ratio }=\frac{\text { Harga Saham }}{\text { Laba per lembar saham }}
$$

Sumber: (Suad Husnan, 200: 76)

3. Return On Asset (ROA)

ROA $=\frac{\text { Net } \text { Profit } \text { After } \text { Tax }}{\text { Total } \text { Assets }}$

Sumber: (Lukman Syamsuddin, 2009:63)

4. Firm Size

Firm Size $=$ Log Total Asset

Sumber: (Mohebbimoghaddam, et al., 2016)

\section{Analisis Regresi Berganda}

Metode analisis data dalam penelitian ini dilakukan dengan regresi linear berganda (Multiple Linear Regression) yang menggunakan perkiraan regresi. Bertujuan untuk menguji dan menganalisis pengaruh dari variabel independen terhadap variabel dependen pada perusahaan yang bergerak disektor industri barang konsumsi pada perusahaan manufaktur sub 
sector makanan dan minuman yang tercatat aktif di Bursa Efek Indonesia. Data ini diolah menggunakan SPSS. Perkiraan persamaan regresi yang digunakan adalah sebagai berikut:

$$
\text { Return Saham }_{\text {it }}=\beta_{0}+\beta_{1} \text { EPS }_{\text {it }}+\beta_{2} \text { PER }_{\text {it }}+\beta_{3} \text { ROA }_{\text {it }}+\beta_{4} \text { Size }_{\text {it }}+\varepsilon_{\text {it }}
$$

\section{Uji F}

Uji F digunakan untuk menguji signifikansi pengaruh EPS (Earning per Share), PER (Price Earning Ratio), ROA (Return On Asset), dan Firm Size terhadap Return saham secara simultan. Langkah-langkah yang dilakukan adalah (Gujarati, 1999):

Menentukan tingkat signifikansi yaitu sebesar $0.05(\alpha=0,05)$.

\section{Analisis Koefisien Determinasi $\left(\mathbf{R}^{\mathbf{2}}\right)$}

Koefisien determinasi $\left(\mathrm{R}^{2}\right)$ digunakan untuk mengukur seberapa jauh kemampuan model dalam menerangkan variasi variabel dependen. Nilai koefisien determinansi adalah antara 0 dan 1. Nilai $\mathrm{R}^{2}$ yang kecil berarti kemampuan variabel-variabel independen dalam menjelaskan variasi variabel dependen amat terbatas (Ghozali, 2005). Nilai yang mendekati 1 (satu) berarti variabel-variabel independen memberikan hampir semua informasi yang dibutuhkan untuk memprediksi variasi variabel dependen.

\section{Pengujian Hipotesis (Uji t)}

Pengujian secara parsial menggunakan uji t (pengujian signifikansi secara parsial). Pengujian secara parsial ini dimaksudkan untuk melihat seberapa jauh pengaruh satu variabel independen secara individual dalam menerangkan variasi variabel dependen. Langkahlangkah pengujian yang dilakukan adalah sebagai berikut (Gujarati, 1999):

a. Merumuskan hipotesis (Ha)

Ha diterima: berarti terdapat pengaruh yang signifikan antara variabel independen terhadap variabel dependen secara parsial.

b. Menentukan tingkat signifikansi $(\alpha)$ sebesar 0,05

\section{Hasil Penelitian}

\begin{tabular}{|c|c|c|c|c|c|c|}
\hline \multicolumn{7}{|c|}{$\begin{array}{c}\text { Tabel } 1 \\
\text { Hasil Uji F } \\
\text { ANOVA }^{\mathrm{a}}\end{array}$} \\
\hline & Model & $\begin{array}{l}\text { Sum of } \\
\text { Squares }\end{array}$ & df & $\begin{array}{l}\text { Mean } \\
\text { Square }\end{array}$ & $\mathrm{F}$ & Sig. \\
\hline 1 & $\begin{array}{l}\text { Regression } \\
\text { Residual } \\
\text { Total }\end{array}$ & $\begin{array}{l}1,666 \\
6,661 \\
8,327\end{array}$ & $\begin{array}{c}4 \\
50 \\
54\end{array}$ & $\begin{array}{l}, 417 \\
, 133\end{array}$ & 3,127 &, $023^{\mathrm{b}}$ \\
\hline
\end{tabular}

a. Dependent Variable: SR

b. Predictors: (Constant), SIZE, ROA, PER, EPS

Dari hasil analisis regresi dapat diketahui pula bahwa secara bersama-sama variabel independen memiliki pengaruh yang signifikan terhadap variabel dependen. Hal ini dapat dibuktikan dari nilai $\mathrm{F}$ hitung sebesar 3,127 dengan probabilitas 0,023. Karena probabilitas jauh lebih kecil dari 0,05 atau 5\%, maka model regresi dapat digunakan untuk memprediksi return saham atau dapat dikatakan bahwa variabel Earning Per Share (EPS), Price Earning Ratio (PER), Return On Asset (ROA) dan Firm Size secara bersama-sama berpengaruh terhadap Return saham. 
Tabel 2

Hasil Uji Model $\left(\mathbf{R}^{2}\right)$

Model Summary ${ }^{\mathrm{b}}$

\begin{tabular}{|l|l|r|r|r|r|}
\hline Model & $\mathrm{R}$ & R Square & Adjusted R Square & Std. Error of the Estimate & Durbin-Watson \\
\hline 1 &, $447^{\mathrm{a}}$ &, 200 &, 136 &, 3649920 & 1,977 \\
\hline
\end{tabular}

a. Predictors: (Constant), SIZE, ROA, PER, EPS

b. Dependent Variable: SR

Dari hasil perhitungan diperoleh hasil besarnya pengaruh variabel independent terhadap variabel dependent yang dapat diterangkan oleh model persamaan ini adalah sebesar 13,6\%. Hal ini menunjukkan bahwa besar pengaruh variabel Earning per Share (EPS), Price Earning Ratio (PER), Return On Asset (ROA), dan Firm Size terhadap Return saham yang dapat diterangkan oleh model persamaan ini adalah sebesar $13,6 \%$ dan sisanya sebesar $86,4 \%$ dipengaruhi oleh faktor-faktor lain yang tidak dimasukkan dalam model regresi, seperti faktor ekonomi negara secara makro, faktor sentimen pasar serta faktor politik negara. Melihat kecilnya pengaruh variabel independen terhadap variabel dependen, maka perlu adanya kehatihatian dalam melakukan generalisasi atas hasil penelitian ini.

Tabel 3

\section{Hasil Perhitungan Regresi Berganda}

\begin{tabular}{|c|c|c|c|c|c|c|}
\hline \multirow{2}{*}{ Model } & \multicolumn{2}{|c|}{$\begin{array}{c}\text { Unstandardized } \\
\text { Coefficients }\end{array}$} & $\begin{array}{c}\text { Standardized } \\
\text { Coefficients }\end{array}$ & \multirow{2}{*}{$\mathrm{t}$} & \multirow{2}{*}{ Sig. } \\
\cline { 2 - 5 } & B & $\begin{array}{c}\text { Std. } \\
\text { Error }\end{array}$ & Beta & & \\
\hline \multirow{4}{*}{1} & (Constant) &, 273 & 1,147 & &, 238 &, 813 \\
& EPS &, 000 &, 000 &, 257 & 1,716 &, 092 \\
& PER &,- 001 &, 002 &,- 075 &,- 528 &, 600 \\
& ROA & 1,005 &, 444 &, 325 & 2,265 &, 028 \\
& SIZE &,- 030 &, 092 &,- 049 &,- 319 &, 751 \\
\hline
\end{tabular}
berikut :

Dengan melihat tabel diatas, dapat disusun persamaan regresi linear berganda sebagai

Return Saham= 0,273 + 0,000EPS - 0,001PER + 1,005ROA - 0,030FirmSize

\section{Pembahasan Hasil Penelitian}

\section{Hipotesis 1 : Earning Per Share (EPS) berpengaruh signifikan terhadap return saham}

Berdasarkan hasil penelitian earning per share tidak berpengaruh terhadap return saham. Hasil ini disebabkan oleh adanya fluktuasi pada data earning per share (EPS). Hal ini mengindikasikan bahwa earning per share (EPS) yang menurun menandakan investor tidak mau lagi menanamkan sahamnya pada perusahaan tersebut. Akibatnya laba perusaaan akan semakin menurun, sehingga earning per share (EPS) tidak mempengaruhi harga saham. Hasil penelitian ini didukung oleh hasil penelitian terdahulu yaitu dari Bowen et al (1986) yang menunjukkan bahwa Earning per Share (EPS) merupakan variabel yang tidak signifikan dalam menerangkan return saham.

\section{Hipotesis 2 : Price Earning Ratio (PER) berpengaruh signifikan terhadap return Saham}

Dari hasil penelitian ini diperoleh tingkat signifikansi untuk variabel price earning ratio (PER) sebesar 0,600 dimana lebih besar dari 0,05 atau 5\%. Sehingga hipotesis yang kedua ini tidak dapat diterima. PER dapat memberikan petunjuk mengenai apa yang dipikirkan investor atas kinerja perusahaan dimasa lalu dan prospeknya dimasa yang akan datang. Price earning ratio (PER) tidak berpengaruh terhadap return saham disebabkan PER lebih banyak 
berhubungan dengan faktor lain diluar return saham. Hasil penelitian ini mendukung hasil dari penelitian Muhammad Muzid Afwan (2013), dimana penelitian tersebut menghasilkan price earning ratio tidak berpengaruh terhadap return saham.

\section{Hipotesis 3 : Return On Asset (ROA) berpengaruh signifikan terhadap return Saham}

Berdasarkan hasil penelitian ini return on asset (ROA) berpengaruh signifikan terhadap return saham. Dari hasil penelitian ini diperoleh tingkat signifikansi ROA sebesar 0,028 dimana lebih kecil dadri 0,05 atau 5\%. Oleh karena itu, hipotesis ketiga diterima. Hal ini menjelaskan bahwa semakin besar ROA berarti kinerja perusahaan tersebut semakin baik, karena tingkat kembalian (return) semakin menghasilkan keuntungan berbanding dengan aset yang relatif tinggi.

\section{Hipotesis 4 : Firm Size berpengaruh signifikan terhadap return Saham}

Dari penelitian ini diperoleh tingkat signifikansi dari variabel firm size sebesar 0,751 dimana lebih besar dari 0,05. Hal ini berarti hipotesis keempat tidak diterima, karena firm size tidak berpengaruh terhadap return saham. Hal ini menjelaskan bahwa perusahaan besar mengindikasikan tingkat pengembalian yang kurang baik. Dimana, dalam teori akuntansi positif menyatakan bahwa ukuran perusahaan digunakan sebagai biaya politik dan biaya politik tersebut juga akan meningkat seiring dengan ukuran perusahaan dan risiko perusahaan (Watts dan Zimmerman, 1978 dalam Sukartha, 2007). Hasil penelitian ini mendukung penelitian Yani (2014) dimana hasilnya menunjukkan bahwa firm size berpengaruh tidak signifikan terhadap return saham.

\section{Kesimpulan}

1. Earning Per Share (EPS) tidak berpengaruh terhadap return saham.

2. Price Earning Ratio (PER) tidak berpengaruh terhadap return saham.

3. Return On Asset (ROA) berpengaruh signifikan terhadap return saham.

4. Firm Size tidak berpengaruh terhadap return saham.

\section{Daftar Pustaka}

Arista, Desy dan Astohar. (2012). Analisis Faktor-Faktor yang Mempengaruhi Return Saham (Kasus Pada Perusahaan Manufaktur yang Go Public di BEI periode tahun 2005-2009). Jurnal Ilmu Manajemen dan Akuntansi Terapan, 3(1), h: 1-15.

Farkhan dan Ika. (2012). Pengaruh Rasio Keuangan terhadap Return Saham Perusahaan Manufaktur di Bursa Efek Indonesia. Jurnal Bisnis dan Manajemen. Vol 9, No 1.

Hardiningsih, Pancawati, Suryanto. L, Chariri, Anis. (2002). Pengaruh Faktor Fundamental dan Risiko Ekonomi Terhadap Return Saham Pada Perusahaan di Bursa Efek Jakarta (Studi Kasus Basic Industri \& Chemical), Jurnal Strategi Bisnis, Vol. 8 Th. VI pp. 8396.

Jogiyanto, Hartono. (2010). Teori Portofolio dan Analisis Investasi. Yogyakarta: BPFE

Kasmir. (2004). Manajemen Perbankan, Cetakan Kelima, PT Raja Grafindo Persada, Jakarta.

Saqafi, Vahid and Hamidreza Vakilifard. (2012). The Effect of Variables of The Fundamental Techniques on Returns of The Stock in Tehran Stock Echange. Interdisciplinary Journal of Contenporary Research in Business, 4(3), pp: 808-813. 